\title{
DOCUMENTS
}

Anatoli Ilyashov

\section{VICTOR REUTHER ON THE SOVIET EXPERIENCE, 1933-35: AN INTERVIEW}

Born in 1912 in Wheeling, West Virginia, Victor G. Reuther has played a major role along with his brothers, Walter and Roy Reuther, in establishing the United Automobile, Aircraft and Agricultural Implement Workers of America. He has held numerous positions that have dealt with union affairs. During the Second World War he was co-director of the UAW's war policy committee and also a labor member of the War Manpower Commission. In 1946 he became the UAW education director. He was appointed the head of the Congress of Industrial Organization's European office in 1951, and later became an administrative assistant to the President of the CIO in 1953, and to the President of the UAW in 1955. As the director of the UAW's International Affairs Department, Reuther was at the heart of a controversy in 1967 concerning labor's foreign policy. In 1971 he retired from his union positions. Currently, he is involved in the debate within the UAW on the merits and consequences of the General Motors Saturn Project in Tennessee.

Reuther was interviewed by me in Washington, DC, in January 1986. The interview involves a period of his life when he and Walter left the United States in 1933 for a three-year world tour. About half of that time was spent in Gorky in the Soviet Union, where they were employed as skilled workers at the Gor'kovskii Avtomobil'nyi Zavod helping to inaugurate production of the Ford Model $A$ passenger car and the Ford Model AA light truck.

After returning home in 1935, he secured employment the next year in Detroit, Michigan, in the automobile industry. With the urging of Walter, he became involved in organizing automobile workers at UAW Local 174 in West Detroit. He was one of the leaders of the 1936 sit-down strike at the Kelsey-Hayes Wheel Company plant there, and shortly thereafter participated in what was to be known as the Great General Motors Sit-Down Strike in Flint, Michigan, in 1936-37. Subsequently, he was sent to Indiana in 1937 to become the UAW director of organization there. His labor 
activism and union official work spans more than thirty-five years in the American labor movement. He is the author of The Brothers Reuther and the Story of the UAW: A Memoir (1976). At 74 years old, Reuther currently lives with his wife, Sophie, in Washington. They have three children and a number of grandchildren. He has established himself in his free time as an accomplished craftsman in the skill and intricate art of woodblock work.

Question. I am interested in the Americans going over to work in the Soviet Union in the early to mid 1930 's. I think it's good to take a look at the Americans there and what it meant to them and what it meant overall. Looking at your book, I found it well loaded with information about that period. Again, when did you go there?

Answer. Well, it was in the fall of 1933. As a matter of fact, we lived through, what is I think, the last free election that existed in Germany prior to the complete takeover by Hitler. That would have been in November of 1933. We left shortly thereafter on the train from Berlin to Warsaw and Moscow.

As a matter of fact, we had hoped to go in much earlier. One of the reasons why we spent so much time wandering around through Europe is that our visas to enter the Soviet Union for work had been delayed for reasons that we found very difficult to understand because we had expected a few months after arriving in Europe in February 1933, that we'd be on our way to work in the plant. But here we were stranded in Europe and we took advantage of that opportunity to sort of cycle around and see what was happening and at each Soviet Embassy in each major city we came to, whether it was Paris or London, or Berlin, we'd check on what the status was of our applications for visas. It finally came through, but it was late in the fall.

I remember being in Berlin to witness that final election, such as it was, and we boarded a train within a matter of a few days thereafter for Moscow. Question. What you're referring to are the elections that would eventually bring Hitler to power?

Answer. Yes. That's quite right. Yes, because we witnessed the rise of Hitler to power, the burning of the Reichstag, the brutalization that followed in many regions where trade unionists were brutally beaten and socialists and communists, of course, anyone in opposition. It was a terrible thing to witness really.

Question. Did you have a formed opinion about Naziism at that point? Answer. Well, I think so. We came from a democratic-socialist family. 
Everything that Hitler symbolized was anathema to us and from the moment of our arrival in Germany and all of the days that we were there, most of our contacts were with young student groups, young worker groups who were oriented toward the Social-Democratic Party. And they were all in opposition. As a matter of fact we helped some young student leaders escape from raids which young brown trooper - Nazi storm troopers - had carried out on student headquarters in Berlin and elsewhere.

Question. When you got to Moscow, you had some news for them (the Soviets), so to speak, from experience?

Answer. Well yes, and of course there were quite a few Germans who had already preceded us there as technicians, whom I assume volunteered for that work because they wanted to get out of Germany before Hitler took over. And later of course we were joined by large numbers of Austrians who fled into the Soviet Union after the 1934 uprising.

Question. So you left, as you say in your book, around November 1933 ?

Answer. That is from Berlin, yes, that is right. Yes we left the States as early as February, as I recall of ' 33 .

Question. And you went to Moscow?

Answer. Yes, which was a stopover point only for change of trains on the way to Gorky. ${ }^{1}$

Question. To get the visa, was it very difficult to say: "Well I want to be one of the people who works at Gorky, an auto worker", as part of the technical, skilled people? Was that hard to get?

Answer. I'm sure they did an awful lot of clearing, and checking with people. We had friends who had worked with Walter [Reuther] ${ }^{2}$ in the Rouge tool room [at the Ford River Rouge Plant], who had already reached

1 Gorky, formerly the mediaeval city of Nizhni-Novgorod, is a major urban industrial center in the Russian Soviet Federated Socialist Republic and the administrative center for the Oblast' (Province) under the same name, located some 260 miles east of Moscow. It was renamed in 1932 in honor of Maksim Gorky (pseud. for Aleksei Peshkov), the well-known writer, who was born there in 1862 .

2 Walter Reuther later was to became the President of the UAW in 1946, President of the $\mathrm{CIO}$ in 1951, and a Vice President of the AFL-CIO and head of the Industrial Union Department after the merger in 1955. His union activities started before the Gorkyautomobile-plant experience as a tool and die worker. Upon his return to the United States from his "world tour" with his brother Victor, he successfully organized automobile workers into UAW Local 174 on Detroit's West Side and became its president in 1935. In 1936 he was elected to the international executive board of the UAW, and later by 1939 became the director of the UAW's General Motors Corporation department and elected first vice-president of the UAW in 1942. His union career involved extensive work in the UAW, the CIO and the AFL-CIO, and ended with his unfortunate death in an airplane crash on May 10, 1970. 
Gorky and were working there under contract, and who knew of Walter's skill. They didn't know me. But they knew of Walter's skill and highly recommended him so that we assumed that we had some friends inside who were pushing.

But it wasn't until we actually arrived in Gorky that we were told that the reason for the delay was that they had no housing accommodations for foreign workers. And our visas were delayed until they built these temporary structures. And of course, when we arrived there we were housed in and for the duration of our stay - in what could only be called sort of twostory military barracks, which were rather primitive in their structure. The only insulation was manure that was put in between sheets of plywood and then some kind of "furring" on the outside you know. It was a marvelous feeding ground for the cockroaches in the winter!

Question. Now, there were a number of technicians that you mentioned in your book. There was a recruitment campaign. By 1931 there were certain exchanges. There was recruitment of more technical labor by ' 31 and onward. Was there also recruitment for unskilled workers?

Answer. Oh, I don't think so, no. They would accept some unskilled workers if they were a part of the family unit. They zeroed in on the specific skills that they needed.

Each basic industry - steel, auto, chemicals, textiles, and so on - had their own recruitment offices for foreign personnel. And there was established in New York, an office of Avtostroi, ${ }^{3}$ for the purpose of facilitating recruitment. Then, of course, single firms, like the Ford Motor Company, which had entered into contracts with them, were used for recruiting purposes also. They were used to train large numbers of young Soviet technicians. For instances, the Ford Motor Company had some 300 to 350 Soviet technicians who came over and were trained in the River Rouge

\footnotetext{
3 Avtostroi was the Soviet automotive branch or "trust" that was established to promote the development of automobile production in the Soviet Union. It became based in the Detroit area after negotiations were completed with Ford Motor Company in 1929. Amtorg Trading Corporation, as the official trading organization of the Soviet Union dealing with the United States, is an American corporation subject to the laws governing such entities within the United States; the main office is in New York. Currently, major shareholders of Amtorg are the Bank for Foreign Trade and the Central Union of Consumers' Co-operatives of the USSR. Among its functions, it supervises and assists in the servicing of contracts with companies, conducts on behalf of foreign-trade associations export and import operations in the American market, and assists Soviet foreigntrade companies in the transport of cargoes and technically related questions that arise in business dealings. In the 1930's it was an important agency in the United States for facilitating technical transfers of labor and machinery, and fostering favorable trade relationships.
} 
Plant ${ }^{4}$ at a time when Walter was still working there, before we went. So this training took place quite early.

It took place, I would say, soon after Knudsen - that's William Knudsen, who later became president of General Motors -, he was then an official in the Ford Motor Company. And he was the one who went to the Soviet Union and negotiated with the Soviet leaders, including personal meetings with Stalin. He negotiated the assistance program - the sale of the tools of the Model A car, when they finished production at River Rouge; the training of Soviet personnel at the River Rouge plant; and the sending of some technicians to help get the tooling underway in the plant. So that you had people recruited by the Soviet agencies directly, or by the Ford Motor Company.

Then you had some volunteering who for political reasons, or because it appeared to be an exciting experience, such as that which tempted Walter and I. You had people coming for many different reasons and through many different channels. But I think all of them were designed to meet an obvious void or lack of a cadre of skilled personnel [in the Soviet Union].

One of the earliest groups that was recruited were those for structural work - cement work, for instance. There was a very heavy recruitment that was undertaken, especially among Finnish immigrants in the United States. I think the largest number were recruited from the Northwest, around Seattle, who apparently had a good deal of experience in structural cement work. And I presume quite a few of them felt friendly for political reasons too because at that time the Russian Revolution had quite an appeal to many who looked upon it as a great liberating movement.

I am quite sure the Communist Party was crucial in promoting that kind of recruitment. They were among the first that went there because they had to prepare the basic plant sites and get up the structures before they could bring the more skilled workers in for directing the machinery and getting the production lines in shape.

Similar recruitment went on in other countries. While you asked about the Americans, there were quite a large number of Italians who were antiMussolini, anti-fascist. Whether they were socialists or communists, I really can't say. But they were anti-fascists. Some of whom were skilled workers from the more highly developed industries around Turino, ${ }^{5}$ who found their way to Gorky. There were some Polish immigrants. An occasional Britisher - not many. So that you had quite a collection of people from different

4 The Ford Motor Company's River Rouge complex, located in Dearborn, Michigan, in the Detroit vicinity.

5 Turin, the automobile center of Italy, housing Fiat. 
countries, speaking different languages, in the Gorky auto works.

They were housed in what was called the Ruthenberg Commune, named after the American communist leader. ${ }^{6}$ And it was the structures in that center which were apparently behind schedule that delayed the granting of visas for many of us during '33.

Question. There were two different types of workers, you mentioned. In monetary terms I would call them the "dollars" and "rubles" employees. Answer. You bet. First and second class! When the Soviet government signed a contract with an American firm or a British firm, there was a certain number of skilled technicians whose presence was essential for carrying that out. When the Soviet government made such contracts, that limited number of skilled personnel were guaranteed income in dollars or British sterling which was deposited in banks in New York or in London. And they received also a modest amount of rubles for their daily living expenses in the Soviet Union. They were treated with kid gloves and were given very, very special consideration, even imported foods were brought in to assist them. And they ate in special little cafeterias or reserved restaurant areas for skilled foreign technicians.

Those who came under other auspices than Ford Motor Company or Austin Engineering, etc., who were hired directly by Avtostroy or any one of these recruiting agencies, were paid solely in rubles. We were paid solely in rubles. We were paid somewhat better than what the going rate was for a Soviet worker, but the only other advantage that we had, aside from the slightly higher salary scale, we were permitted to buy some items that were highly rationed in a store reserved solely for foreign technicians. And that store was located in the Ruthenberg community and Soviet workers were not permitted to buy there.

This was not to be compared with the Torgsin stores of that period where one could purchase only with dollars or hard currency, or exchange gold for commodities. You recall in the period immediately after the revolution, the Soviet regime made quite an effort to get access to jewelry, gold, and they opened a chain of special stores - Torgsin - as they were called, where one could trade with jewelry or other valuable items and purchase goods that were highly rationed.

We had access to these government stores for foreign technicians, but paid in regular Soviet rubles. We had no access to hard currency. But some items were made available which you could get at that time on the open market. An occasional pair of good shoes would come through or work

6 Charles E. Ruthenberg (1882-1927), a founder and first National Secretary of the Communist Party of America in 1919. 
gloves, which were not available on the open market. Sometimes foodstuffs - butter and meat in very limited quantities - would be available there.

But since we lived in the Commune and ate in the restaurant, we surrendered our ration coupons to the operators of the collective restaurant. Although as foreign technicians we were entitled to a higher ration of butter and meat than what we actually were able to enjoy, the reason for that was we pooled it because there were many children there. There were whole families - Italians, Poles, and others. When that was spread around, it meant that our own individual ration was quite small.

I remember the only time I really saw fresh butter after maybe a six- or eight-month lapse, would be when summer vacation would come and we would go away for a month and cycle, perhaps, or take a boat down the Volga. Our individual ration coupons were returned to us for use during that month, and on the way, we were able to get a little butter for that, and maybe a little vegetable oil or something. Those were difficult days. They were extremely difficult.

Question. How much more than the Soviet workers were you paid?

Answer. Probably about 25 percent more, I would think off hand. Now of course, this depended on one's skill. And there was a degree of piecework or group bonus system, and hence that affected the earnings as well.

Question. How did you feel about that type of piecework or bonus? It didn't matter?

Answer. Well, of course, I never did like piecework, whether it was Stateside [in the United States] or anywhere else. The group system was in effect there, because it was very difficult in the kind of work we were doing to have individual piecework. So it was handled by the group. I must say I always had great difficulty in figuring out how they figured what our group bonus would be. I just never argued about it because I knew that the Soviet members of our brigade whose income was somewhat smaller - and they were obviously on a tighter budget -, I knew that they'd argue for as high a bonus as could be secured. So I didn't have to do that.

Question. Did they have special stores for dollars?

Answer. They did have, but not in our area. They had them in Moscow and Leningrad, and they were called Torgsin stores. When we got into those big cities did we have any occasion to go there. And quite frankly, for the most rudimentary essentials, we managed to get by.

Although I lost some 30 pounds in the first year and I was a very slender lad when I arrived there. Much of that weight loss was from dysentery. I had great difficulty adjusting to the diet. Russian black bread was a wonderful bread, but it had ingredients that I'm still not certain what they were!

They used to tell the story about the tobacco which was smoked by the 
Russians in the plant, and they called it makhorka. They would say that it was one third sawdust and one third horse shit, and the rest may be ground leaves of some kind, but certainly not tobacco! And they would take a plain piece of old newspaper - bumaga - and they'd twirl it into a sort of small cornucopia and fill it with this stuff. And I don't know whether it was the newsprint or the ingredients, but it smelled so goddamned awful that I was never tempted to take up smoking while I was in the Soviet Union.

Question. When you got to Gorky and you saw all the people, did you notice or recognize any Detroiters?

Answer. Not really. There were some from Detroit, but we did not know them. There was some hard core Party people who moved there and took out citizenship. Of course, we knew John Rushton who was a Party member and a very devout one. I always looked upon him as a sort of an intellectual communist who was a very gentle and very sensitive man. To him this was the ideal co-operative society, and he was so devoted. He was a very skilled toolmaker, incidentally, extremely skilled. He was already up in years. He must have been 60 when he moved there. He took his wife and children - he married late - and moved there and took out Soviet citizenship. So we knew him. Walter knew him, because Walter worked with him. I didn't know him. But we didn't know any others there from any prior experiences. Question. You mention him in your book, and also another man named Kadarian.

Answer. Kadarian, yes. He was the guy who got the Order of Lenin. Question. I saw that in the Moscow News, ${ }^{7}$ the May Day edition 1934. Answer. You came across that, did you? Well, there were many, many such incidents, where quite frankly foreign workers, whether they were British or German or Italian or American in those days, they came from industrial societies much more developed than what was commonplace in the Soviet Union.

There were certainly very skilled workers from Leningrad who came to our plant and helped. But most of them were people who came out of peasant villages who hadn't seen anything more complicated than a wheelbarrow or pitchfork in their lives and suddenly they're asked to work

\footnotetext{
7 The Moscow News (weekly), begun in October 1930, was supplemented later by another English-language newspaper, the Moscow Daily News, headed by such prominent people as Anna Louise Strong as associate editor and Mikhail Borodin as editorin-chief. It became a mouthpiece for English-speaking workers, who experienced problems in their workplaces and lives. Awards and congratulations were mingled together with individual accounts of frustration in dealing with matters as inefficiency and bureaucracy. It also provided needed world news, and information on national developments and Party analyses.
} 
with micrometers and height gauges that measure within a tenth of a thousandth of an inch. Even if they graduated from the local FZU ${ }^{8}$ apprenticeship school, this was an incredible leap in a few years for them. Hence, they had this incredible curiosity to read any technical book they could get, even if it was fiction. I guess, if there had been books on Star Wars they would have eaten it up in those days! But any technical book they could get their hands on, they just labored over it so.

Of course, a person coming from more advanced industries knew not only because of their actual experience, many simple little things which made them appear much more brilliant than they really were. In those days the whole regime almost worshipped technological advance and anyone who came from an advanced technological society was looked upon as a teacher and instructor. So, ordinary workers going over there appeared to be engineers. That's why Kadarian, who could take ideas that were commonplace from technical books in the States and submit them as new ideas, won all kinds of awards.

Well it was - it seemed like a bit of petty corruption in a way. On the other hand, it was one of the devices that was used to tap the knowledge of the foreign workers who came to stimulate the growth and development of understanding by a whole new generation. And to me it was quite laughable at times.

But as I look back upon it, the whole nation took a quantum leap in an incredible short time. One can only admire all that went into it.

It was something which I think the Western world still hasn't fully grasped - how great a transformation occurred in the lives of people from the Volga country or from the mountains of the Caucasus, some of whom were so primitive, mind you, that when they put them in modern housing buildings, especially those from the Caucasus, some of them would build an open fire in the middle of the floor-seriously! Because that's what they did. They had only lived in tents before. When you bring an older generation along with young people who volunteer to come up and work in the factory, and they've got the close ties with the parents and others, they bring them along. And the younger generation that was exposed to factory life and all

8 FZU or fabrichno-zavodskoe uchilishche refers to factory training or apprenticeship. It also refers to schools for such technical education, or shkoly fabrichno-zavodskogo uchenichestva, which combined classroom instruction along with direct work training in industrial plants. The schools recruit and train young workers, both male and female, usually between 16 and 19 years of age, and have courses of instruction ranging generally from a few months to a year, depending on the trade. See, for example, E. G. Osovskii, Razvitie teorii professional'no-tekhnicheskogo obrazovaniia v SSSR, 1917-1940 (Moscow, 1980), or James Crowther, Industry and Education in Soviet Russia (London, 1932). 
the training that went with it, moved ahead more rapidly than did the parents who were sort of stuck at home and did little odd jobs.

Question. Naturally, that was also one of the most difficult things experienced by humans in industrialization in the Western countries. It was that move from the rural to the urban, from the village to the factory, from an agrarian way of life to an industrial one ...

Answer. That's right. There it was.

Question. Obviously, for the Soviet Union they were very quick jumps . . . Answer. Oh yes. You almost bridged several centuries in a matter of ten years. Incredible.

Question. When you finally got into the factory there, what were the conditions like in there, namely in GAZ or Gor'kovskii Avtomobil'nyi Zavod?

Answer. Gor'kovskii Avtomobil'nyi Zavod [. . . ] imeni Molotova. ${ }^{9}$ I have something downstairs that you will not find in the GAZ Museum. I have the original oval-shaped nameplate from the first Ford car which bears two little hammers and sickles and the Russian letters imeni Molotova [in the name of Molotov]. Well, of course, Molotov was sent to Siberia in disgrace and he's a non-person now.

Walter worked on the die that stamped out that first little nameplate on the radiator. It was a rather tricky little die to build [. . .].

Question. Compared to standards you'd been familiar with in the United States, what would you say now about that plant and how it operated?

Answer. One can't really draw a parallel. This whole area there was one huge construction site. They were not only building the factory, but they were building a city to house 50,000 inhabitants. Incidentally, the whole city was heated from the exhaust of the power plant. The power plant was the first building that was put up. There were just piles of dirt and piles of building material everywhere.

Some of the huge buildings where manufacturing was already getting underway, still hadn't sealed off one end of it because huge trains were moving equipment in and they had some kind of a flimsy drape over it to try to keep the bitter wind out. But when it's 20 below or 30 below zero outside, you can't keep any kind of proper temperature inside. I remember in the tool room the first winter there, one of our biggest problems was that the temperature was so low that one had to work with gloves! And yet you can't

9 Literally, GAZ stood for the Gorky Automobile Plant or Works, which after its completion as the new major industrial automobile complex for the Soviet Union in late 1931, assembled Ford Model A cars and Ford Model AA trucks of the 1930 vintage. It was named in honor of V. M. Molotov, Chairman of the Council of People's Commissars of the USSR from 1930 to 1941. 
do precision work with gloves. Also, there was the change in temperature from machining a piece of metal, which increased the temperature of it considerably to the temperature when it was cold. The contraction of the metal changed the dimension of it considerably. It was not possible to really function within close tolerances of thousandths of an inch under those kind of circumstances. Often we'd have to move into the heat-treat department where it was warmer. We would even take a piece of machinery in there and finalize it, because the changing temperature out in the main work area was so low.

Then you had this heavy equipment being moved around by overhead cranes and cables on which heavy equipment including heavy dies, weighing several tons - heavy castings, with sharp edges -, would be balanced precariously on very heavy steel cables, which would become shredded because of the sharp edges of the casting. But to try to balance it precariously on there anyway - because these cables would get a kink in it and once it started to lift up and the full weight was borne - it would shift, and sometimes those heavy castings would fall. There were injuries and there damages done to very expensive equipment that had to be purchased aboard for valiuta - for dollars, for hard currency.

One of the things Walter raised hell about very early in our arrival there [. . . ]. When I say raised hell about, we were trying desperately to do what we could to help them to improve production, to improve efficiency. And, of course, it is common practice in all countries where heavy dies are made, that you drill the casting on the side, and you thread it, so that you can screw in a hook. You then take a heavy cable which has a permanent ring attached to one end of it, and just hook it into that. Hook the loop onto the hook on the casting, right, and lift it up.

Walter suggested that they automatically bore the edge, the side of every casting, which is the base, the foundation, on which the precision tool is inserted and fastened - right. And it's the heavy base, and when it's in the press it has to be very sturdy and heavy.

The first response of the Soviet engineers in the Department was what purpose does that hole serve after the die is made. Well, it really serves a purpose if you want to move it. They were terribly anxious to cut corners, and quite frankly there were some things in Western countries for sort of spit and polish purposes that didn't help functionally. They were operating under a sort of wartime pressure, and quite frankly they anticipated war soon after anyway. So, I can well understand that they were eager to cut as many unnecessary corners as they could.

They said: "This is a waste of time, we're not going to do this." Here they were balancing these damned things, and I remember I think Walter wrote 
an open letter to the Moscow Daily News on that one, criticizing their sort of bureaucratic attitude, which didn't take into consideration the dangers to the workers and the danger to very, very expensive zip-boring mills and other things which cost many, many thousands of dollars.

Anyway, you asked about comparison. Well, God, we worked three months and didn't build a single die that functioned because at some point, some part of that die was bound to be scraped, if not in the initial layout, then in the machining. If not in the machining, then in the hardening. If not in the hardening, then in the grinding. At some point, all of these trainees that were a party to making this, were bound to make errors. And there were some parts of a single die that were made over eight and nine times. But it's interesting that in the months before we left, they were making-oh, I don't know the exact figure any more - but I think it was six or eight dies a month.

That was an enormous change in a very short period. They did learn. They paid a heavy price for it. But they did learn.

Once the plant was closed in and we had heat, there were better working conditions. But then, for instance, a simple thing like having cotton waste material to wipe off a surface which you had spread vitric acid on to turn it a copper color so that when you scribed it and laid out the cutting edge you could visibly see where it was to be machined. In most places they will have bales of waste material that you can use to just wipe that off. There was nothing to wipe it with. A young trainee in our brigade used to wipe it off with the sleeve of his jacket. After three days he had no sleeve! It just ate it all away. He didn't realize what he was doing. When we saw him doing this, we said: "My God, you're not going to have any sleeve on your jacket any more."

But there was no waste material to use for that. You had no used newspapers or anything. There was nothing that we consider available as scrap was available there. What in hell do you use to wipe it off with? Well, they didn't think about that and they weren't about to spend money to buy it either. So, we had to improvise whatever we had. It was difficult, I can tell you.

Question. Working conditions, did they improve?

Answer. Oh, they improved. They improved greatly in a very short time, really. Of course, we had many meetings, many discussions, raising hell about things that could be improved.

We had the changing-shift business, which played havoc too, where you were on days and then shifted to afternoons and then the third shift. The most skilled instructors were on the day shift. Walter, for instance, worked exclusively days because that was the shift where you had to line up the 
others for their work. I went often on the second shift and followed through there. So that the people who worked the second and third shift did not have the skilled supervision that the day shift had. But yet they were following through on the same dies, and that created problems, because the level of skilled administration wasn't as good on night shift or second [shift], as on the day shift.

Question. This was brought out in meetings?

Answer. Oh, yes. They had frequent meetings of the triugolnik, the triangular organization which represented the factory administration, the trade unions and the Communist Party. You had a Party functionary in each department as well as a trade-union functionary and a superintendent. These three formed the triugolnik, the triangular organization which was basic to all of the big industries that were being developed in the early fiveyear plans.

There would be frequent meetings called under the sponsorship of these three and whether it was a trade-union matter or a political matter, or a factory-administration matter, this was the place where it was aired. The trade-union functionary, of course, always reported at those meetings and sometimes he would raise hell with the management about the lack of certain supplies or certain shortcomings, such as in the cafeteria [. . ]. That was typical of the kind of primitive circumstances under which we worked and so on.

I would imagine some of the early pioneering groups that went West and helped set up operations went through similar things. Not on that scale, but working under primitive conditions is hardly an experience restricted to Eastern Europe.

Question. To counter much of this adversity and propel the Plan onward, there were the people within the production brigades or in the department that were referred to as udarniki or "shock workers". Did you take that seriously?

Answer. Oh, yes. They did then. You get a little tired of it after a while, you know, if too damned many of your weekends are given up helping at harvesting or planting trees in the new city, or just cleaning up an area.

It was a form of social activity, also. You must realize that a very high percentage of these young workers were brought in from Volga villages, from Central Asia, from the Ukraine, and there weren't too many social activities. They had a very primitive sort of kino or theater. When you had an outing that was organized to do some work, they'd usually have some music, and you got a little extra something in food also that normally wasn't available. That made it a little tempting, maybe some dessert of some kind.

It was as much a social affair as shock troops for the Party's work, or the 
factory administration's work, when you could feel the immediate results of it yourself, so to speak. If you came from a farm area and labor was short because we dragged so many off the farms for the factory, then when harvest time came, and you came out to help them - well, you brought a few goodies back with you, too. Or, if you planted some trees in what was going to be this new city where you were living - so you had a little greenery to look out on. You didn't feel as though it was always for the other guy or for some absent bureaucracy. Hence, there was good deal of morale at that period.

I know from much later discussions, and later visits, that the fervor went out on a lot of this. How long can you keep a revolution alive? That's understandable. It's like what was done in the sit-down-strike days. You can't be on a permanent strike. A lot of that kind of fervor runs its course. And that was true there.

Question. What did the final product, this car model produced at Gorky look like?

Answer. The first car we built was the Model A Ford, with no changes on it at all. It was not until they began tooling for their own model. What they did was they made a few changes in it. They took some body lines from an old Packard car and worked it into the first so-called all Soviet model.

While we were there, the car that was run off was the standard Model A Ford. And they made no changes in that at all except in the plate on the radiator, the name plate. Otherwise it was - it was a perfect - it was a good car. I think even the Ford officials who were there to see it through to the first run, felt that it was a good car. Maybe not with all the spit and polish on finish that we had on the Model A in Detroit.

But it was a perfect car for that period, when the roads were very bad. The car was built high, and it was an excellent car for the muddy roads of Russia. It was a car that you could repair with a piece of haywire, so to speak. It was quite a simple car in its construction.

Question. Was the American Village the same thing as the Ruthenberg Commune you mentioned earlier?

Answer. Yes, [ . . ] it was built adjacent to a little peasant village.

Question. How far from the factory?

Answer. Oh, maybe two miles. Not more than that. A nice walk. Less than that to the power plant, to the closest edge of it. But to where I worked it was about two miles, and probably four miles to Sotsgorod, the socialist city where most of the workers were housed.

I think when they first started building the village for the foreign workers, it was referred to by the local Soviets as amerikanskii poselok, because the bulk of them who came were Americans. But then when Poles and Italians 
and others started coming, more seeking political asylum than as recruited technicians. The Americans were recruited technicians in large part. There were some who came out of political considerations.

Anyway, it was called the American Village, I don't think the name Ruthenberg Commune was used nearly as much. That was probably to please some party officials back here, and they gave it that name.

Question. In that setting were you able to communicate with the Russians and the other Soviet peoples?

Answer. We had plenty of communication with them. We had a small cultural center there and local soviets would come there for many functions. Some for discussion of economic matters where a new economic program was put through. Or, if there was a change in the rationing allocation, there would be an official coming to make a presentation there. And the Soviet citizens would come too.

Some of the Americans took Soviet wives. When there was a social affair, Russian girls used to love to come and congregate there for several reasons. One, there was a chance of marrying a foreigner. That was always an attraction to them at the time; and there was the possibility also of getting something from the local store via an American, which they couldn't get otherwise.

Then, of course, in the factory, one was encouraged to take part in subbotniks, in outings that were organized for the whole department. So we went on many outings like that with the Soviets. We were not isolated in a ghetto in that sense, not at all. We were encouraged to have lots of contact and we did.

We did organize a German singing society after many Austrians came after the uprising of ' 34 . We were toured to many Soviet factories, and performed, singing the Blue Danube to the accompaniment of maybe a fifty-piece orchestra. You know, big stuff! [. . .]

This served a very useful propaganda purpose for the Soviets. Here they were, giving refuge to freedom fighters.

Question. So you knew German pretty well?

Answer. Oh yes, yes.

Question. How did you do in Russian? Did you know any Russian?

Answer. I guess I had a proficiency in languages somewhat better than Walter's. But I also became very attached to a young Russian girl and she helped me enormously as another lovely young Russian girl helped Walter learn. That's normal. The Russian winters are very long and the nights are terribly long too, and one seeks comfort and companionship. And we did. And we learned a good deal that way.

I guess the radio was helpful too. We had a lot of radio of our own, but the 
one in the dining room was always carrying news and so on. So one hears the language a great deal when you're living there.

Of course, you have to use it in the plant. They assigned us an interpreter, an Austrian, not a Schutzbunder ${ }^{10}$ not a recent arrival, but a guy who had fled during World War I into Russia. He was a Czech, but his citizenship was Austrian. His name was Dvorni. He spoke German to me and translated from German into Russian. That's another reason why my German improved.

There had been very, very few English interpreters and translators who could work at the shop level in the plant. They had a special office to take care of problems of foreigners about passports and all this kind of stuff. They had a guy there who spoke English perfectly. But otherwise, we had to lean very heavily on Dvorni for interpretation. Then, when the Schutzbunders came, we had occasion in our social activities in the community there, and in the plant, because the Schutzbunders when they came, they knew no English and they knew no Russian. All they knew was German. I had to provide some sense of direction to them. I had to use German. But Russian came to me, well, I shouldn't say easily, but relatively quickly. Question. Was the technical language difficult?

Answer. Oh, extremely difficult. The only thing that helped there was they absorbed many English words. We had to work with English blueprints, and we had to work in both inches and millimeters because all of the dies all of the blueprints for the Model A were in inches. And yet they were converting everything to millimeters. So we had to work in both the metric system, as well as inches. That got a little complex. But fortunately, since we were using Ford Motor blueprints, which were duplicated there and available, they took on and absorbed many of the English words.

That's quite normal in most countries where a major country with a different language comes in with blueprints and everything. They start absorbing all the words. But, that was a stumbling block. Also, it was a stumbling block because I did not know those technical words in German, so I had to learn them in German as well.

I had a little German and English and Russian dictionary, a little knizhka that I would carry in my pocket and consult frequently. I also had to consult that to ask the girl if she'd go walking with me.

10 Schutzbunder or Schutzbündler was a term used to describe Austrians who were part of the abortive insurrection against right-wing elements in the Austrian government. It was derived from Schutzbund, which was the Social Democratic Party's own armed force in the 'twenties and early 'thirties, and a descendent of the People's Guard of 1918. See Ilona Duczynska, Workers in Arms: The Austrian Schutzbund and the Civil War of 1934 (New York, London, 1978). 
Question. You also had the opportunity of participating in "volunteer labor" brigades, or subbotniki that went into the countryside on weekends? Answer. Rarely overnight, rarely overnight. They didn't have facilities for that. But you would drive out - leave early in the morning. There would be a central assembly place, usually at either the factory or at a point in Sotsgorod where the bus would pick you up and you would go.

In the summer [sic] we did a lot of help in harvesting. Mostly, the subbotniki were organized around the development of amenities in the new socialist city - planting trees, developing a park area, doing some construction work for the new palace of culture that they were putting together. The first ones were extremely primitive, sort of barrack-like structures. I have somewhere photographs of these early ones, and as I look at them today, it's kind of hard to believe that we came through, because now they're big beautiful buildings with marble and lovely theaters. They give courses in ballet and art [...].

Question. Did you ever have contact with the countryside?

Answer. Oh sure. Not to spend any real time. But we would - whenever we have a free day and we weren't volunteering for things. In the summer, we would cycle out into the countryside and stop in. Frequently, a peasant family would invite us to have a little something to eat with them - some fried potatoes and onions, and maybe a little fresh cottage cheese. That was great and we'd always have a little something we could leave for them. They were very happy and excited to see Americans. Many of them hadn't seen any before. So we got to know all those little villages around there. And then, of course, we used to visit the parents of our respective girlfriends. They looked upon us as maybe prospective son-in-laws. They didn't know we weren't that serious. But anyway, one got to know them quite well too. Question. Did you have any sense of the collectivization that was happening at that time? Because you were in a factory setting, and the factory was quite separate from the countryside, did you feel the magnitude of the collectivization that was going on?

Answer. We knew that the first collectivization had led to much of the shortages of food, especially meat and milk, butter fats. There was a slogan during the forced-collectivization period, "Eat, drink, and be merry. Tomorrow we join the collective." A family that had maybe a dozen or twenty head of cattle, figured: "What the hell, if we're going in on the same basis as some krestianin [peasant] who has no cow at all, we might just as well enjoy it before we go in." So they had a great orgy, and this triggered, of course, terrible famine because they killed a lot of their seed cattle, their breeding cattle. It wasn't too long before the effects of that were felt throughout the length and breadth of the Soviet Union. 
Question. Evidently, collectivization must have been a very difficult process for everyone. Moreover, it was tied to a number of political developments at that time associated with Stalin and later with the purges. I don't know what you faced at that time. What was happening?

Answer. We were so involved in the development of the new industry that I don't know that there was much forced collectivization in agriculture in the immediate Volga area there, comparable to what developed in the Ukraine. But I do know that many, many of the workers who came into the new auto plant came from rural areas in the Ukraine and in the mountainous regions of the Caucacus, and from lower Volga areas further down toward the Black Sea.

My first impression was of the incredible impoverishment of the peasant groups who came. There was a very very small percentage, no more than 5 percent of the labor-force in the plant that came from families that one could possibly describe as middle-class, that came from families that had a fair degree of culture and learning.

One young man who impressed us very much, who later became the leader of the brigade and took over when we left, and is, as far as I know, now the superintendent of the whole tool-and-die department, Vladimir Vladimirsky. His father was a railway worker. Now that put him in an upper stratum. It was quite obvious from the very first day that we met this young worker, that he came from a cultured family that had considerable education. He learned very rapidly. His habits of dress and speech were not that of a peasant.

But the number of Vladimir Vladimirsky's was very, very small. The bulk of the workers came out of either mountain families in the Caucasus or of Central Asia, or from peasant villages. And they had very little schooling, and very little cultural training, very little cultural background. They were extremely primitive. They had, for instance, no personal association or knowledge of indoor toilets. Now that may appear rather shocking to us, but there weren't many indoor toilets even among middle-class Russians in those days. So one has to realize how primitive all of the country really was.

Many of these primitive personal habits intruded into the factory. It was very difficult, for instance, to get them to use modern lavatory facilities. They would stand on the seat! They didn't know one was to sit on them. In order to prevent that, they built a bar across so that you couldn't stand. You had to squat. You had to sit. Now that seemed quite ludicrous to us, but that was a very ingenious way of training them to adapt to modern lavatory facilities.

Question. What did you know about those peasant families that underwent collectivization? 
Answer. Although I visited some collective farms, I have little knowledge as to what those same families - what their lives were like before collectivization. Nor did they speak openly to a foreigner about that. That would have been rather difficult, I think, for them to do.

Question. What did you undergo personally after another difficult watershed in Soviet history as the assassination of Sergei Kirov, ${ }^{11}$ an event that would bring on the massive purges of the second half of the 1930's? Answer. I did live through a very traumatic experience shortly after the leader of Leningrad, Kirov, was assassinated. The Stalin regime launched a nationwide campaign to ferret out those traitors who were responsible for the Kirov assassination. Of course, history now shows this was all a great cover-up, because Stalin and Beria themselves were responsible for assassinating Kirov. But Stalin used the murder of this very popular Leningrad official, who was so popular he constituted a threat and a challenge to Stalin's position. Stalin used this as a basis for ferreting out any potential opposition to himself and his regime.

Hence the evidence that was presented, such as it was in the official trial was re-broadcast over public address systems in the factories all over the country, and this became the backdrop for local trials in the factory of local people who came under suspicion. The whole Party apparatus was mobilized and people under threat of terrible discipline were forced to squeal and tell on others of whom they had suspicion of not being loyal.

Hearing this public broadcast of the evidence and the manner in which it was presented, it was McCarthyism magnified a thousand-fold and then projected into the plant. You were told now you've got to continue this in your own plant, in your own department, in your own housing block, etc.

It was a frightening thing to experience. It really was. I remember hearing in little meetings that were held in the department where workers were called upon to tell what they knew about others, and the fear and the trembling that preceded their testimony was a pitiful thing to witness.

Question. This had to be starting in late' 34 and thereafter. The other thing that was looming at the time was what we talked about at the beginning that was the war, the Reichstag fire, and Hitler. War-preparedness was an issue by 1934.

Answer. It was more than talk, and it was more than training young kids to

11 Sergei Kirov, in charge of the powerful Leningrad Party organization since 1925, became a member of the Politburo in 1930 and a Secretary of the Central Committee of the Party in 1934. He was suddenly assassinated on December 1, 1934, in the Party headquarters of the well-known Smolny building in Leningrad, which precipitated what was to come to be known as the great purges of the 1930's. There continue to be varying interpretations as to who the instigator of Kirov's death was. 
parachute. Every park, every factory, every housing development had a place off of which they could jump with a parachute.

Inside the factory there was great preparation for that military preparedness. We were tooled to build the Model A Ford, but at the same time the Red Army sent engineers into our tool room, and we designed and built dies to stamp out parts for gun carriages, tanks, and other military hardware.

Now, this was an automobile plant, but it is obvious that the machines that produce automobiles, or the machines that produce airplane parts, can produce tanks and vice versa. They are multi-purpose tools. It depends on the kind of die you build and what kind of parts are stamped out by it. These dies were tested. The first samples [.. .] were stamped out, taken and examined by the Red Army, and found satisfactory. It was stamped as approved and put on the shelf under guard behind heavy wire fencing, inside the factory as reserves, anticipating that that plant would in very short order be converted to making military hardware. And of course, it was converted sometime after we left.

We know full well that that plant was converted in very short order to making tanks and gun carriages, and of course, special heavy military trucks carried probably other kinds of military hardware. And the plant has been greatly expanded since for permanent military production.

As a matter of fact, I wanted to go to see the village where the amerikanski poselok was, and they said: "Oh, the village is not there any more. That's now been built as part of the industry." And I said: "Oh I'd like to go there anyway." But we were not permitted to go there. Those buildings are now producing some kind of military equipment. But we did get through the balance of it, which is producing - continues to produce automobiles, but a more recent version.

Question. The possibility of war for the Soviet Union was quite real even in the years that you were there. Later developments bear out a lot of the Soviet's fears. In '39 you have this pact with Stalin and Hitler, and by 1941 there is already declared war between the Soviet Union and Germany. So, in 1934 and 1935 you were already seeing a preview of things to come.

Answer. Yes. Well, it's quite obvious that that pact was signed to buy time. They knew that they were going to be involved in the war and they bought time through that pact.

But it also taught us a lesson that we remembered well when we came back home. We got into the great debate about conversion to war production, and the leaders of the American automobile industry - General Motors, Ford and Chrysler - did not want to convert their automobile plants to war production. They wanted them to be put on a standby basis. 
They wanted the government to build spanking new plants which would have taken several years to build, and hence would have delayed conversion by several years.

Walter led the fight to convert the automobile industry to build 500 planes a day, and General Motors laughed and said: "Ridiculous, these are special-purpose tools to make automobiles, not airplanes." But at the end of the war these corporations boasted about how they converted and used $89 \%$ of the automobile equipment for military production!

Question. This then was taken from experience...

Answer. This was still fresh in mind. We remembered the Red Army engineers coming in and the tools being built for stamping out military's hardware, and some of that could have been for aircraft as well as tank cars. We weren't privy to knowing precisely what parts these were for. But we knew it was all military. And we saw them oiled up and put on the shelf ready to use. So that if the Russians with more primitive equipment, and a much more primitive labor-force could convert that quickly, we knew we could here too. That certainly was a lesson we remembered when we got into war production here, absolutely.

Question. That's an incredible story.

Answer. Yes, it is. When you think about how totally irresponsible the corporate structure was in not accepting what their responsibility to the nation was. They knew damned well those plants could turn out those parts, but by God they were thinking about being in a more favorable position at the end of the war. So, they could quickly start running out automobiles again for a fast buck. They would have brand-new, spanking new plants that they could get for a buck - for one cent on the dollar. The aircraft industry pulled this off many many times. But I think World War II taught us a lesson that isn't likely to be repeated again.

Question. Did you experience any famine during this time? They started having famine problems in ' 30 and ' 31 and onward?

Answer. When we arrived in Gorky and got out of the train station and boarded a streetcar, the streetcar was so jammed with people. It was the only transportation out to the factory. There was no other transportation available. And there weren't many of those. People sitting on the roof, people hanging literally from the side of the streetcar, hanging onto the window frames. Incredible. When they realized we were foreigners, they gave way and let us get inside. But we were in such a crush that our hands were pinned at our sides and there wasn't anything we could do. We had our suitcases with our skilled precision tools in them, which were heavy, at our feet. Our pockets were slit open with razor blades and some of our possessions taken, diary books. They didn't get our passports and they got very 
little money.

Who did it? Well, in those days there were literally millions of homeless street waifs, the besprizornyi, homeless street waifs who had to make a living by stealing. There was no other way. I'm sure this was the residue of the forced collectivization and the famine, and every city, every village, had the scourge of the homeless street waifs. It was with great effort that the Soviet Union rounded them up and put them into big old estates that were converted into training rehabilitation centers where they taught them some kind of a trade and a craft. Several of the workers on our brigade had been homeless street waifs. They admitted it to us and they came through the FZU apprenticeship school.

The visible things of famine were so prevalent in '33. By the fall of ' 34 , it began to improve somewhat. By the time we left [in mid 1935], the availability of bread, for instance, which was the great staple [. . .]. I shall never in my life waste a piece of bread without a guilty conscience after what I lived through in the Soviet Union, because I have seen people fight over a small crust of bread. The physical violence that is used to just get access to a little food is something which [. . .] we had heard of in Asia. I had never expected to witness [this] in Eastern Europe. But it was a terrible period they went through.

Question. While you were seeing this, were you given the news of what was happening in the depressionary West?

Answer. Well, the Soviets had quite a propaganda campaign underway then with huge posters. I remember they were entitled: $U$ nas, u nikh- "By us and by them", at home and abroad. They showed harvesting crops and well-fed peasants, and then the unemployed lines, the bread lines in New York. They made quite a propaganda story of that.

I don't think I ever met any Soviet citizens who really believed the people were hungry in America because the only Americans they met were so obviously affluent. They were well-dressed, they had access to precision tools, height gauges, micrometers. They couldn't bring themselves to believe the Party's propaganda.

I think that was a little premature on the part of the Soviets. I think maybe today they might put on some of that kind of propaganda because there is unemployment and there is hardship in Western industrialized countries. They are much more affluent. I don't think one sees that kind of hunger on the streets any more in the Soviet Union.

Question. Looking back at your experiences, how do you look at the Soviet Union today and what it is, what is represents to you?

Answer. Well, I developed a very warm feeling for the Russian people. I really did. I like the Russian people. I have come to enjoy their music and 
their language and their culture. I see the enormous progress which they've made in terms of raising the living standards, of bringing education to the vast population which they have.

I feel great sadness that the price they've paid for this in terms of political bureaucracy, lack of freedom of travel, and so on. This is, I think, an unnecessary indignity which the Russian people are being submitted to. Quite frankly, I think a regime that isn't internally strong enough to permit the people to speak their own mind, that denies them a chance to travel and see how other people live and make comparisons, that regime doesn't deserve popular support. And I think it will go through some changes. I hope it won't be as drastic as were changes in the past. But I think there will be changes.

They can't keep the lid on indefinitely. Modern technology makes communication possible across nations. It will not be possible for them to keep the Soviet people ignorant of what's going on in the rest of the world. And the knowledge of what's going on will increase their thirst for travel, will increase their pressures for change inside. And it will come. And one of my great hopes is that instead of trying to compete with the Soviets in building missiles, that we would challenge them by opening wider the borders and making it easier for people to have contact, because the change that's going to come will result form that kind of contact.

The more you threaten their regime, the stronger a hold the military regime has over its people. And our people would react the same way. You confront us with an external threat, and we'll all unite behind Ronald Reagan, even those who think he's no damned good. And that's what has been happening. They have unified their people based upon the fear of attacks from abroad. We have to lessen that.

Question. What were the lessons for the labor movement - this whole experience of the '30's? Are there any? Was there any impact on the American labor movement?

Answer. Very little, I think. Very little. The US trade-union movement has been slower to learn from international experiences than the farm community, than the intellectual community, and other institutions, because we have become ideologues in terms of foreign policy. We're fighting the Cold War, and we're really solidifying the regime's support inside the Soviet Union. Our approach has been very negative, I think, and self-defeating. This is an area in which I have my sharpest disagreements with the American trade-union movement. You don't have to believe in communism. You don't have to accept communism to believe that they have a right to whatever kind of system they want to live under. And we ought to help them have a great exchange of ideas with people of other countries - Asia, 
Africa, Latin America, and so on.

Question. When the people that went there came back, did some of them become trade-union members that were prominent leaders? Besides the Reuther brothers, of course?

Answer. Well, I don't know of any other case insofar as US citizens are concerned. I think there were young Austrian workers who returned, some of whom were sent back by the Communist Party, immediately after the war, to try to consolidate their position in Austria.

Many who went with great political hopes - some of whom were actual party members, Communist Party members - came back quite disillusioned. The story of John Rushton, I think, and what happened to his family was quite an eye-opener. He became quite disillusioned and his family broke up and his wife returned. His daughter, who was the apple of his eye, married a young Russian engineer, and she was killed in a bombing during the war. And something happened to him also. The whole family was just wiped out.

Then, of course, there was the story of Victor Herman. He wrote a book about his experience in the Soviet Union. ${ }^{12} \mathrm{He}$ was a young aviator. His parents came and worked in the Gorky plant. He is from Detroit. He has a sister who is still active in the trade union, although I think she has retired now $[\ldots]$. .

Victor Herman's family went there, he was a small boy. I remember the boys, but they weren't of the age to be working in the plant yet when we were there. They did later. So he worked in the plant where his father was working. And he became a flyer and quite a hero, I guess, as an aviator in the Red Army. He became terribly disillusioned and was sent to a gulag. $\mathrm{He}$ had one hell of a time getting out.

None of them returned to do any political work or trade-union work. This became the end of their life there. Some of their kids, that's a different matter though. Children who were taken there and hadn't made the choice themselves to go, that's a different matter. I never made any study of what happened to the children of any of those families, I'm sure many of them have come back [. . .].

Question. Around 1930 there was an exchange of some Soviet and American technicians, even at the Ford Motor Company . . .

Answer. In the River Rouge Plant, yes.

Question. How did you feel about seeing those Soviet technicians? Did you care?

Answer. I was not in the Ford plant that time. Walter was. Walter was in the

12 See Victor Herman, Coming Out of the Ice: An Unexpected Life (New York, 1979). 
tool room. And Walter remembers seeing a large number of Soviet technicians there who were being trained. They were in the plant at the time the Ford hunger march ${ }^{13}$ occurred, and the workers were shot and beaten up by Harry Bennett's guys.

Apparently, there was no negative reaction on their part. At least, Walter didn't pick up any reaction from them. He was quite shocked. Walter was horrified about the shooting of the Ford hunger marchers. Henry Ford was an idol, he was a god, to the Soviets at that time. And he could do no wrong. I don't know how this was explained to the Soviet technicians about what the hell was taking place out on the streets. But they certainly saw a lot of it and they knew about it. They weren't cut off from it. Question. What's a fair way of going at this subject?

Answer. I don't know whether there's another area in the world that's gone through a similar development stage where foreign technicians that might be an interesting comparison. I doubt very much, whether you'll find anything that's quite a parallel with it, because here you had quite a sizable group of people who were motivated politically to want to go there to help build a socialist state. Then you had others who went there purely for economic reasons when the Ford Motor Company or Austin Company said: "Hey, we'd like you to go over to help us." There's been a lot of that kind of thing in Arab countries on oil exploration and so on.

This was a strange mixture of entrepreneurial selling of services to a state, plus the use of people with political motivation. It's very interesting. I doubt very much whether there is a parallel to it.

What I think is interesting is that the Soviets found this extremely helpful at that period. They don't want to reminisce about it today, I don't think. I

13 Often referred to as the Ford Massacre, it took place on March 7, 1932, when the Unemployed Councils scheduled a hunger march on the Ford plant in Dearborn, Michigan, to present the Company a list of fourteen demands, including such demands as jobs for unemployed Ford workers, a seven-hour day with no reduction in pay, a slowing down of "speed-up", an end to job discrimination against black workers, the right to organize into unions, and the abolition of the paramilitary Ford Service Department, noted for its surveillance of and strong-arm tactics among employees. With banners that read: "We Want Bread, Not Crumbs", and "Tax the Rich and Feed the Poor", the approximately three thousand demonstrators were told to stop by the police when they reached the Dearborn cityline. The protesters continued on with a barrage of teargas shot at them by the police and with streams of icy water by firefighters dispatched to the scene. Countering by letting loose a barrage of stones, they were met by bullets that were fired into the crowd by the police. Four people were killed (and in all likelihood a fifth, a black, was killed) and as many as sixty were wounded. As head of the Ford Service Department, Harry Bennett had a major role in devising this outcome. The Detroit prosecutor's office placed the blame for the bloodshed on the Communists and not the police. 
think they want to downplay their dependence on foreign technology. They want to beat the nationalist drums that they raised themselves by their own bootstraps. Well, they did, no question about it. But they had a helping hand.

What is interesting is the special amenities which they had no difficulty in providing for foreign workers, and how those special amenities now have been passed on to the elite, to the upper echelons of the bureaucracy, the special stores, the special coupons for buying things that are not available to the local citizens. An almost separate economy within an economy. They heralded the day when they closed the special stores for the foreign workers as having marked their reaching that point of economic development that it was no longer necessary to provide these extra amenities to attract foreign workers. But they justified the continued existence of them for their own bureaucracy. 